\title{
Singing the helplessness blues
}

\author{
Simon Cavanagh
}

The UK pop charts have played a part in chronicling, even forecasting the effects of recession on its population - The Specials' Ghost Town (Dammer, 1981) was the number one record a week before the last significant British riots, in the summer of 1981.

It appears to me, having to consider what London's economy will look like in 2062, the question this proposition poses is eloquently captured in Seattle's Fleet Foxes' 'new normal' anthem, Helplessness Blues (Fleet Foxes, 2011), but more of that later.

As London bumps along the bottom of a recession, it is very difficult to forecast ten years ahead, let alone fifty. It takes a leap of imagination to see how current or prospective Londoners will be able to put down roots in its clay and how they will contribute economically.

Working to deliver affordable housing in London, I am more aware than most of the many existing and prospective tenants' fragile grip on their communities, now described by many as exclusive or privileged locations. It would appear that Central London has no need for key workers or an increasingly marginalised working class, both of whom have played a major part in defining this city's economic past.

The globalised technology and financial services industries, held up as some of the keys to unlock London's economic future, will require educated and skilled workers. I doubt many of the next generation that will make up the workforce in 2062 will come from families in temporary or severely over-crowded homes. Adults and children need space and security to thrive, not a permanent state of rootlessness.

Many of London's core industries that had been their preserve are either gone, re-located or, as with the construction industry and its apprenticeships, more than ever focused on providing properties that attract buyers for their use as investment safe-havens. Less common are the hundreds of thousands of homes successive London Mayors have promised to support. There are some but not enough.

We have been here before, and so has London. The city has been shaped by fires, blitzes and economic downturns in its 2,000 year history, and all classes were present and correct then. What is a housing crisis compared to plague?

How to cite this book chapter:

Cavanagh, S. 2013. Singing the helplessness blues. In: Bell, S and Paskins, J. (eds.) Imagining the Future City: London 2062. Pp. 127-129. London: Ubiquity Press. DOI: http://dx.doi.org/10.5334/bag.r 
So, either we imagine London 2062 as a gated community, populated by hedge-fund managers who take it in turn to serve school dinners and turn down hotel beds, or we keep calm and try and reflect.

We have to trust that the foundations of London's economic future will be laid in a re-instated Academy building programme; schools that focus and prepare young Londoners for a more competitive and globalised workplace. Just one graduate, Adele Adkins, has helped to re-energise a once moribund British music industry through a small independent record label. We will need more of her.

We have to trust that London's economy will be fuelled in part by the design, if not the manufacture of actual goods that can compete on a world stage with the best of the BRICS economies. We have to trust that these products will not all be missiles and smart gadgets, designed for fashionable obsolescence or oblivion. Goods that people need and want: Roberts radios, Dyson vacuum cleaners; industries that maximise profit through graft, skill and good design rather than smoke, mirrors and speculation. We will need more of those.

We have to trust that the wages will be decent enough, and the jobs fulfilling enough, to have supported the workless back into London's economy. We have to trust that they will be respected and valued for what they do and not what they earn.

We have to trust that Londoners will want to commute by better and more affordable public transport built and master-planned by governments that recognise the benefits of long-term investment in local infrastructure, not just the stuff that connects us to Europe and the world.

We have to trust that the homes Londoners return to, and want to invite their friends to, will be built to social housing standards in inner-city land banks and in a suburbia that has extended past a green belt that previously marked out the back gardens of a suspiciously high number of second homes.

We have to trust that all Londoners will once again be in a position to save for their future, but will also be more discretionary in their food-spending, so that the farms outside are not forced to sell their wares at a loss to a small number of wholesalers.

We have to trust that London stops for a moment and considers collaboration rather than competition with other post-industrial cities. In return, we have to trust that the governments of those other cities will recognise that London grew by offering a welcome, a possibility to succeed to everyone. That they will act accordingly, so that their citizens' best and brightest option isn't to have to leave. To be honest, London today feels like one of those places.

Many people have moved to London to make their fortune and to keep it close and that is their choice and their right but there are also many more that will come who, in the words of the Fleet Foxes, 'Would rather be a functioning cog in some great machinery serving something beyond them' (Fleet Foxes, 2011).

I think that line encapsulates the best of what it is to be a Londoner.

If London's economy isn't serving those aims in 2062, then it is likely that it will have had its day and it will be Hong Kong or Hamburg's turn. We can be more like Detroit with shades of Monte Carlo at its centre.

Many of us won't be around long enough to be proved right or wrong on our forecasts, but I hope we all spend the next few years laying some of the foundations to position this beautiful and cruel city somewhere between the boom and bust that have defined the previous fifty. Balance and the Fleet Foxes hold the key.

\section{References}

Dammer J. 1981. Ghost Town. The Specials. 2 Tone: CHS TT17; Vinyl recording. Fleet Foxes. 2011. Helplessness Blues. Bella Union: B004LQ19E0; Compact disc. 


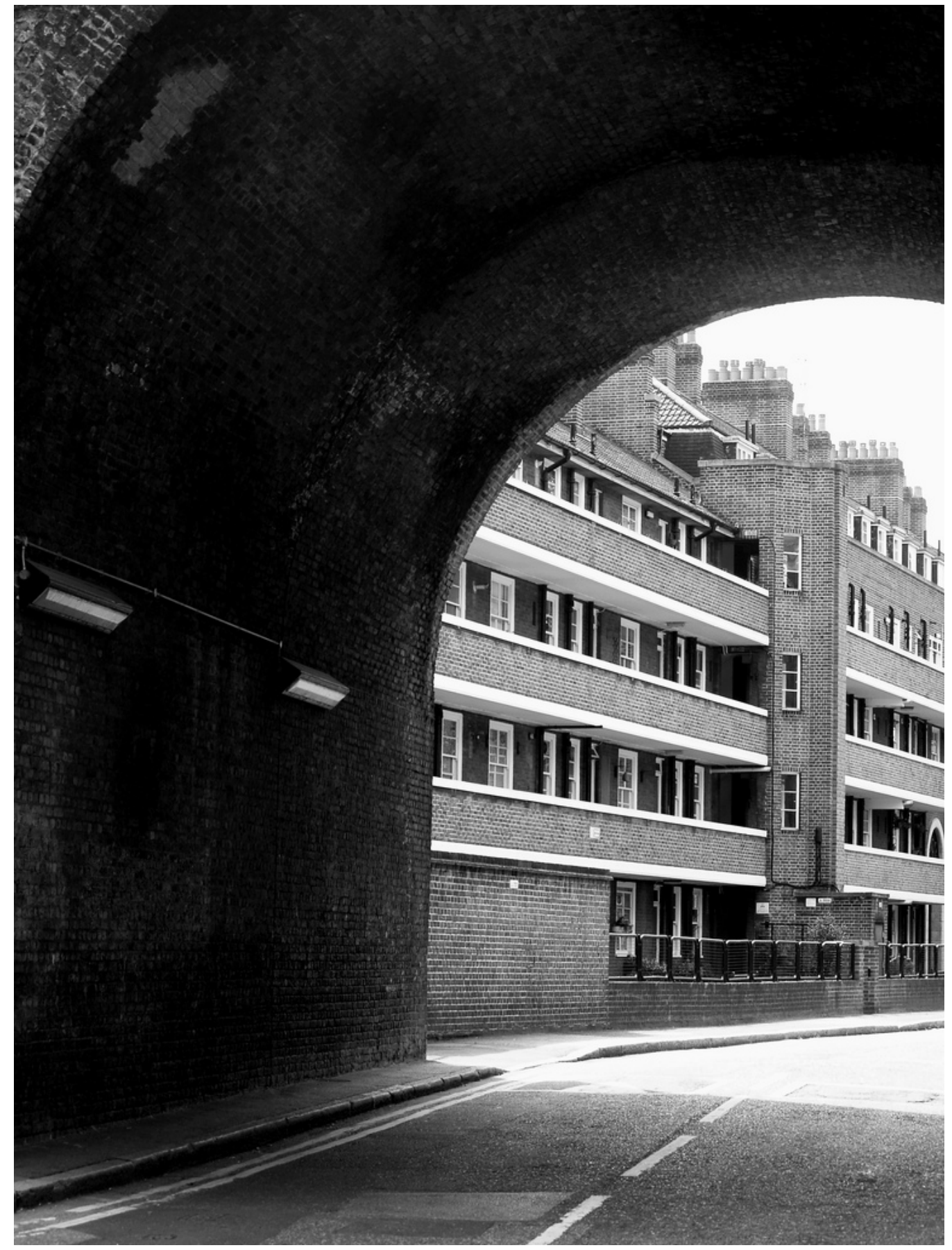

